\title{
ASSOCIATION OF CAFFEINE INTAKE AND LIVER FIBROSIS IN PATIENTS WITH CHRONIC HEPATITIS C
}

\author{
Kalinca da Silva OLIVEIRA ${ }^{1}$, Caroline BUSS $^{2}$ and Cristiane Valle TOVO'1,3
}

\begin{abstract}
Background - Caffeine consumption has been associated to decreased levels of liver enzymes and lower risk of fibrosis in patients with hepatitis $\mathrm{C}$ virus. Objectives - This study aimed to evaluate the association between caffeine consumption and inflammatory activity or degree of liver fibrosis in patients with hepatitis C virus infection. Methods - A cross-sectional study of patients with chronic hepatitis C virus infection treated in an outpatient Gastroenterology Unit of Santa Casa Hospital (Porto Alegre - Brasil). Patients were interviewed regarding the consumption of caffeine and anthropometric assessment was performed. Liver biopsy was performed in a maximum period of 36 months before inclusion in the study. Results - There were 113 patients, 67 (59.3\%) females, $48(42.5 \%)$ were aged between 52 and 62 years, and $101(89.4 \%)$ were white. The average caffeine consumption was $251.41 \pm 232.32$ $\mathrm{mg} /$ day, and $70(62 \%)$ patients consumed up to $250 \mathrm{mg} /$ day of caffeine. There was no association between caffeine consumption and inflammatory activity on liver biopsy. On the other hand, when evaluating the caffeine consumption liver fibrosis an inverse association was observed. Conclusions - The greater consumption of caffeine was associated with lower liver fibrosis. There was no association between caffeine consumption and inflammatory activity.
\end{abstract}

HEADINGS - Caffeine. Chronic hepatitis C. Liver cirrhosis.

\section{INTRODUCTION}

Caffeine is a pharmacologically active alkaloid of the group of methylxanthines ${ }^{(34)}$. It is a liposoluble substance absorbed quickly and efficiently through the gastrointestinal tract with $100 \%$ bioavailability ${ }^{(26)}$. It is present in many types of foods such as chocolate, teas, energetic drinks and coffee, the latter being the main source of this substance ${ }^{(4,9)}$. It is considered the most used psychoactive substance in the world and about $80 \%$ of the population makes daily use ${ }^{(7)}$.

Some authors have demonstrated an inverse association between coffee intake related to several inflammatory diseases ${ }^{(1,12)}$ mortality and markers of inflammation ${ }^{(20)}$, although not all the studies are consistent $^{(21)}$. Coffee consumption has also been associated with a reduced risk of many chronic diseases, including type 2 diabetes mellitus, Parkinson's disease, and liver diseases ${ }^{(16,22,30)}$.

Components in coffee, including caffeine, diterpenes $^{(32)}$, and polyphenols ${ }^{(6)}$, have been related to favorable changes in the activity of liver enzymes, such as $\alpha$-glutamyltransferase and aminotransfera$\operatorname{ses}^{(15,18,25,31)}$. Furthermore it has been awarded a lip- olytic action of caffeine, contributing to the reduction of hepatic steatosis in patients with nonalcoholic fatty liver disease (NAFLD) ${ }^{(33)}$. Recently, caffeine consumption has been linked to decreased levels of liver enzymes and lower risk of fibrosis in patients with hepatitis $\mathrm{C}(\mathrm{HCV})^{(11,19,22,29)}$ virus.

The present study aimed to evaluate the association of caffeine consumption and inflammatory activity or the degree of liver fibrosis in patients with HCV in a public tertiary care hospital in Southern Brazil.

\section{METHODS}

This was a cross-sectional study, in which the convenience sample comprised patients with $\mathrm{HCV}$ with or without cirrhosis. It from July 2012 to May 2013, at the Gastroenterology Outpatient Unit in Hospital Santa Casa de Porto Alegre - RS, Brasil.

Patients were consecutively included, considering those over 18 years and those with chronic infection with $\mathrm{HCV}$, defined by a positive anti-HCV test and confirmation of viremia checking the RNA-HCV. All patients underwent liver biopsy in a maximum period of 36 months before study entry. 
We excluded patients with present or past alcohol abuse $(80 \mathrm{~g} / \text { day })^{(24)}$, and those coinfected with hepatitis B or human immunodeficiency virus (HIV). Patients were individually interviewed and caffeine consumption was assessed by a questionnaire. The habitual consumption of caffeine in the last 5 years prior to the liver biopsy was considered. Daily intake of caffeine was calculated as described by Andrade $\mathrm{JB}$ et al..$^{(2)}$ and Fredholm BB et al. ${ }^{(10)}$.

The age of the patients was analyzed according to percentiles (p25/p50/p 75). Anthropometric data comprised weight, height and body mass index (BMI) calculated by the formula weight $/$ height $^{2}{ }^{(36)}$. Patients were not under any nutritional intervention.

Anti-HCV antibodies were detected by ELISA III, according to the manufacturer's instructions (Abbott Axsym System N.Chicago/IL, USA). Subsequently, microparticle enzyme immunoassay (MEIA) was performed, followed by polymerase chain reaction (PCR) in real time.

Liver biopsy was performed as part of the protocol for assessing the indication of treatment of $\mathrm{HCV}$, using the Metavir $^{(3)}$ score for staging. The presence of cirrhosis was assessed by clinical, laboratory and image methods, and histopathological ones when needed.

This research protocol was approved by the local Ethics Committee and presented minimal risk to patients. All patients signed an informed consent form for participation in the study.

The first step of the analysis was to check the distribution of the variables and recoding. For descriptive data analysis means, standard deviations, frequency distributions and percentages were used. Bivariate analyses were used for quantitative (averaging and comparison of averages or $t$ test) and qualitative variables (chi-square). To compare caffeine consumption between sex and skin color, Mann-Whitney test was used.

The association between continuous variables with caffeine consumption was assessed with Spearman correlation coefficient (rs). For controlling of confounding factors to explain the degree of liver fibrosis, multiple linear regression analysis was applied.

For this study, $P<0.05$ was adopted as statistically significant. The processing and data analysis was performed using SPSS, version 18.0.

\section{RESULTS}

A total of 113 patients with HCV were included; 67 $(59.3 \%)$ females, $48(42.5 \%)$ aged 52 to 62 years old, and 101 $(89.4 \%)$ were white (Table 1$)$.

The average caffeine intake was $251.41 \pm 232.32 \mathrm{mg} /$ day, and $70(62 \%)$ patients consumed up to $250 \mathrm{mg} /$ day of caffeine. The patients reported regular consumption of caffeine and unmodified intake in the last 5 years.

There was a significant inverse association between caffeine intake and age (rs=-0.394, $P<0.001)$ (Figure 1). There was no significant association between caffeine consumption and $\operatorname{BMI}(P=0.891)$.
TABLE 1. Characteristics of patients with chronic hepatitis C $(n=113)$

\begin{tabular}{lc}
\hline Variable & Total $-\mathbf{n}(\%)$ \\
\hline Sex & \\
$\quad$ Male & $46(40.7)$ \\
Female & $67(59.3)$ \\
Age in years & \\
$\quad 551$ & $31(27.4)$ \\
$52-62$ & $48(42.5)$ \\
$63 \geq$ & $34(30.1)$ \\
Skin color & \\
White & $101(89.4)$ \\
Non-white & $12(10.6)$ \\
BMI in $\mathrm{kg} / \mathrm{m}^{2}$, mean $(\mathrm{sd} * *)$ & $26.7(5.1)$ \\
\hline
\end{tabular}

* mg/day: day milligrams; **sd: standard deviation

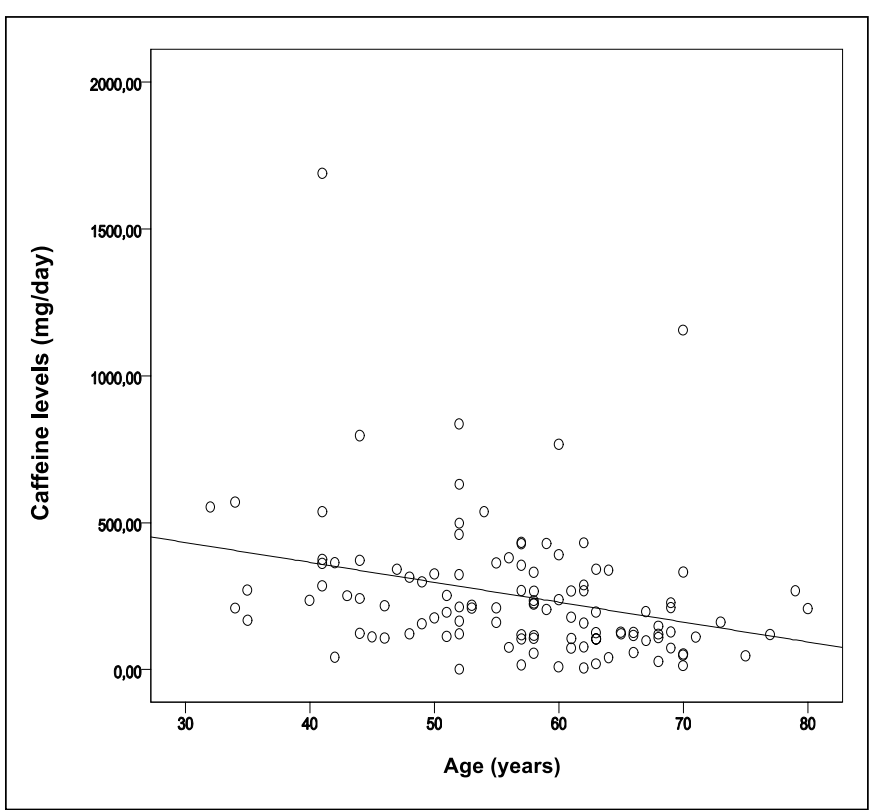

FIGURE 1. Correlation between caffeine intake (mg/day) and age $(\mathrm{n}=113)$

Regarding inflammatory activity on liver biopsy, 45 $(40.2 \%)$ patients were classified as A2 - moderate by Metavir score (Table 2). There was no statistically significant association with measured caffeine consumption according to inflammatory activity $(P=0.942)$.

Regarding the degree of liver fibrosis, $39(34.5 \%)$ patients were cirrhotics (Table 2). When the caffeine consumption was analyzed according to different degrees of liver fibrosis it was observed that the higher the caffeine intake, the lower the degree of liver fibrosis $(P=0.01)$.

These data were repeated in direct correlation analysis, observing that there was no association between caffeine consumption and inflammatory activity ( $\mathrm{rs}=-0.072 ; P=0.451)$ but it was associated with liver fibrosis ( $\mathrm{rs}=-0.338 ; P<0.001)$ (Figure 2). 
TABLE 2. Caffeine consumption and histopathological changes in liver biopsy $(n=113)$

\begin{tabular}{|c|c|c|c|c|}
\hline \multirow{2}{*}{ Variables } & \multirow{2}{*}{$\begin{array}{c}\text { Total } \\
\text { n }(\%)^{* *}\end{array}$} & \multicolumn{2}{|c|}{ Caffeine intake (mg/day)* } & \multirow{2}{*}{$P$-value } \\
\hline & & $\leq 250$ & $\geq 251$ & \\
\hline Inflammatory activity & & & & 0.942 \\
\hline 0. Absent & $18(16.1)$ & $12(66.7)$ & $06(33.3)$ & \\
\hline 1. Low of & $37(33.0)$ & $22(59.5)$ & $15(40.5)$ & \\
\hline 2. Moderate & $45(40.2)$ & $27(60.0)$ & $18(40.0)$ & \\
\hline 3. Enhanced & $12(10.7)$ & $08(66.7)$ & $04(33.3)$ & \\
\hline Degree of fibrosis & & & & 0.01 \\
\hline 0 . Absence of fibrosis & $09(8.0)$ & $03(33.3)$ & $06(66.7)$ & \\
\hline 1. Portal without septa & $15(13.3)$ & $08(53.3)$ & $07(46.7)$ & \\
\hline 2. Portal with rare septa & $27(23.9)$ & $12(44.4)$ & $15(55.6)$ & \\
\hline 3. Portal with numerous septa & $23(20.3)$ & $17(73.9)$ & $06(26.1)$ & \\
\hline 4. Cirrhosis & $39(34.5)$ & $20(76.9)$ & $09(23.1)$ & \\
\hline
\end{tabular}

* mg/day: milligrams per day; **Metavir score

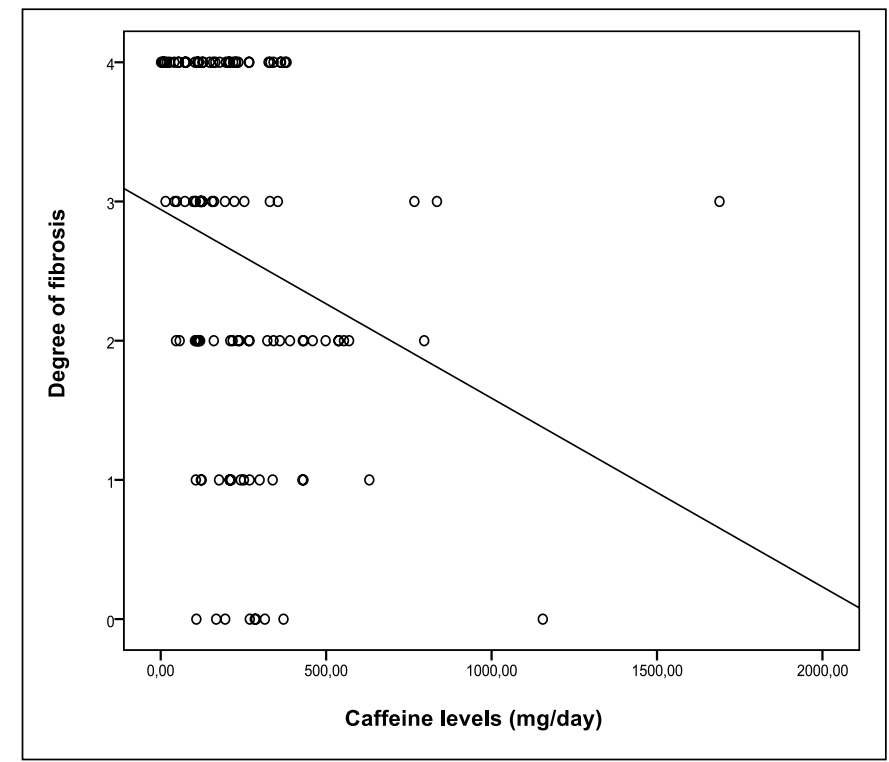

FIGURE 2. Correlation between caffeine intake $(\mathrm{mg} / \mathrm{day})$ and the degree of liver fibrosis $(\mathrm{n}=113)$.

In multiple linear regression analysis, after adjustment for age, sex, skin color and caffeine to explain the degree of fibrosis, age remained a risk factor associated with the degree of fibrosis $(\beta=0.348, P<0.001)$. Caffeine levels were borderline in relation to the degree of fibrosis $(\beta=-0.153, P=0.106)$.

\section{DISCUSSION}

The data in this study demonstrated an inverse relationship between caffeine intake and liver fibrosis, but no association with inflammatory activity was observed.

Several studies in the literature have suggested the beneficial effect of coffee among individuals with chronic liver disease $^{(5,8,13,17,29,35)}$, identifying an inverse association between inflammatory activity, fibrosis and caffeine consumption ${ }^{(22.31)}$.
So far, no one knows for sure if coffee affects spontaneous $\mathrm{HCV}$ seroconversion or the response to $\mathrm{HCV}$ therapy among chronically-infected patients ${ }^{(28)}$.

Metabolic effects of caffeine responsible for liver protection are uncertain and it is suggested that an antioxidant effect could be beneficial ${ }^{(15)}$.

In the present study, no association between inflammatory activity and caffeine was observed. These findings are corroborated by the study of Modi et al. ${ }^{(22)}$, which also found no association between inflammatory activity and caffeine.

As for the progression of fibrosis it has been suggested that increasing intake of coffee is associated with a lower risk of advanced ${ }^{(23)}$ fibrosis. Thus, it is suggested that coffee antifibrogenic may have some mechanism that could prevent progression of the disease.

Any treatment modality that may potentially prevent the progression of fibrosis in chronic liver disease, especially if it confers few adverse effects, has the potential to improve morbidity and mortality ${ }^{(14)}$. In this sense, a Norwegian population-based study demonstrated an inverse relationship between coffee consumption and mortality in cirrhotic patients ${ }^{(35)}$

Freedman et al. ${ }^{(11)}$ demonstrated in a prospective study with 766 patients that the higher caffeine consumption is associated with lower degrees of fibrosis in patients with chronic liver disease, especially those with chronic HCV infection. Other studies ${ }^{(8,13)}$ confirmed these results.

In this study, patients who consumed a larger amount of caffeine per day had more mild fibrosis and the ones who consumed lower amounts presented more advanced fibrosis. Freedman et al. ${ }^{(1)}$ has suggested that the beneficial effect requires caffeine consumption above a threshold equivalent to about two cups of coffee per day ( $\geq 222 \mathrm{mg}$ of caffeine).

We observed an inverse association between mean age and the degree of liver fibrosis, the youngest being those with less fibrosis, probably due to the shorter length of disease progression. Importantly, the progression of fibrosis 
depends on several factors, such as age over 40 years at the time of infection, consumption of alcohol above $80 \mathrm{~g} /$ day, being male, among others ${ }^{(27)}$. The analysis of these factors is relevant, since the degree of fibrosis could be related to some of these, and not the consumption of caffeine. In the present work, we observed that caffeine cannot yet be considered a statistically independent factor to explain the degree of fibrosis. Although patients did not report changes in patterns of caffeine intake over time, this result may not accurately reflect the consumption during the progression of liver disease, which may be considered as a limitation of the study. Nevertheless, the assessment of caffeine consumption was performed following previously published literature.

In conclusion, the higher caffeine intake was associated with a lower degree of liver fibrosis in $\mathrm{HCV}$-infected patients. There was no association between caffeine consumption and inflammatory activity.

\section{Author contribution}

Tovo CV conceptualized and designed the study; Oliveira KS collected and analysed the data and wrote the manuscript, with significant contribution of Tovo CV and Buss C; all authors approved the final version of the manuscript.

Oliveira KS, Buss C, Tovo CV. Associação do consumo da cafeína com o grau de fibrose hepática em pacientes com hepatite C crônica. Arq Gastroenterol. 2015,52(1):4-8.

RESUMO - Contexto - O consumo de cafeína tem sido relacionado à diminuição dos níveis de enzimas hepáticas e menor risco de fibrose em pacientes portadores do vírus da hepatite C. Objetivo - O presente estudo tem por objetivo avaliar a associação do consumo da cafeína com a atividade inflamatória e o grau de fibrose hepática em pacientes com infecção pelo vírus da hepatite C. Métodos - Estudo transversal, constituído por pacientes com infecção pelo vírus da hepatite C atendidos no ambulatório de Gastroenterologia do Complexo Hospitalar Santa Casa (Porto Alegre - Brasil). Os pacientes foram entrevistados e avaliados individualmente quanto ao consumo de cafeína e antropometria. A biópsia hepática foi realizada em um período de no máximo 36 meses antes da inclusão no estudo. Resultados - Foram avaliados 113 pacientes, sendo 67 (59,3\%) do sexo feminino, $48(42,5 \%)$ apresentavam idade entre 52 e 62 anos, e $101(89,4 \%)$ eram de cor branca. O consumo médio de cafeína foi de $251,41 \pm 232,32 \mathrm{mg} /$ dia, sendo que $70(62 \%)$ pacientes consumiam até $250 \mathrm{mg} /$ dia de cafeína. Não houve associação entre o consumo de cafeína e a atividade inflamatória na biópsia hepática. Por outro lado, quando avaliada a associação entre o consumo de cafeína e fibrose hepática observou-se relação inversa. Conclusões - O maior consumo de cafeína apresentou associação com menor grau de fibrose hepática. Não houve associação entre o consumo de cafeína e a atividade inflamatória.

DESCRITORES - Cafeína. Hepatite C crônica. Cirrose hepática. 


\section{REFERENCES}

1. Andersen LF, Jacobs DR Jr, Carlsen MH, Blomhoff R. Consumption of coffee is associated with reduced risk of death attributed to inflammatory and cardiovascular diseases in the Iowa Women's Health Study. Am J Clin Nutr. 2006;83:1039-46.

2. Andrade JB, Pinheiro HLC, Lopes WA, Martins S, Amorim AMM, Brandão AM. Determinação de cafeína em bebidas através de cromatografia líquida de alta eficiência (CLAE). Química Nova. Universidade Estadual de Campinas UNICAMP. Campinas, SP, Brasil. 1995;18:379-81

3. Bedossa P, Poynard T. An algorithm for the grading of activity in chronic hepatitis C. The METAVIR Cooperative Study Group. Hepatology. 1996;24:289-93.

4. Camargo MCR, Toledo MCF. Teor de cafeína em cafés brasileiros. Ciênc Tecnol Aliment. 1998;18:421-4.

5. Casiglia E, Spolaore P, Ginocchio G, Ambrosio G. Unexpected effects of coffee consumption on liver enzymes. Eur J Epidemiol 1993;9:293-7.

6. Cavin C, Holzhaeuser D, Scharf G, Constable A, Huber W, Schilter B. Cafestol and kahweol, two coffee specific diterpenes with anticarcinogenic activity. Food Chem Toxicol. 2002;40:1155-63.

7. Clausson B, Granath F, Ekbom A, Lundgren S, Nordmark A, Signorello LB, Cnattingius S. Effect of caffeine exposure during pregnancy on birth weight and gestational age. Am J Epidemiol. 2002;155:429-36.

8. Corrao G, Zambon A, Bagnardi V, D'Amicis A, Klatsky A. Coffee, caffeine, and the risk of liver cirrhosis. Ann Epidemiol. 2001;11:458-65.

9. De Maria CAB, Moreira RFA. Cafeína: revisão sobre métodos de análise. Quím Nova. 2007;30:586-92.

10. Fredholm BB, Battig K, Holmen J, Nehlig A, Zvartau EE. Actions of caffeine in the brain with special reference to factors that contribute to its widespread use. Pharmacol Rev. 1999;51:83-133.

11. Freedman ND, Everhart JE, Lindsay KL, Ghany MG, Curto TM, Shiffman ML, et al. Coffee intake is associated with lower rates of liver disease progression in chronic hepatitis C. Hepatology. 2009;50:1360-9.

12. Friedman SL. Mechanisms of hepatic fibrogenesis. Gastroenterology. 2008;134:1655-69.

13. Gallus S, Tavani A, Negri E, La Vecchia C. Does coffee protect against liver cirrhosis? Ann Epidemiol. 2002;12:202-5.

14. Gelatti U, Covolo L, Franceschini M, Pirali F, Tagger A, Ribero ML, et al. Coffee consumption reduces the risk of hepatocellular carcinoma independently of its aetiology: a case control study. J Hepatol. 2005;42:528-34.

15. Honjo S, Kono S, Coleman MP, Shinchi K, Sakurai Y, Todoroki I, et al. Coffee consumption and serum aminotransferases in middle-aged Japanese men. J Clin Epidemiol. 2001;54:823-9.

16. Huxley R, Lee CM, Barzi F, Timmermeister L, Czernichow S, Perkovic V, et al. Coffee, decaffeinated coffee, and tea consumption in relation to incident type 2 diabetes mellitus: a systematic review with meta-analysis. Arch Intern Med. 2009;169:2053-63.

17. Klatsky AL, Morton C, Udaltsova N, Friedman GD. Coffee, cirrhosis, and transaminase enzymes. Arch Intern Med. 2006;166:1190-5.

18. La Vecchia C. Coffee, liver enzymes, cirrhosis and liver cancer. J Hepatol. $2005 ; 42: 444-6$.
19. Lai GY, Weinstein SJ, Albanes D, Taylor PR, McGlynn KA, Virtamo J, et al. The association of coffee intake with liver cancer incidence and chronic liver disease mortality in male smokers. British Journal of Cancer. 2013;109:1344-51.

20. Lopez-Garcia E, van Dam RM, Li TY, Rodriguez-Artalejo F, Hu FB. The relationship of coffee consumption with mortality. Ann Intern Med. 2008; 148:904-14.

21. Lopez-Garcia E, van Dam RM, Qi L, Hu FB. Coffee consumption and markers of inflammation and endothelial dysfunction in healthy and diabetic women. Am J Clin Nutr. 2006;84:888-93.

22. Modi AA, Feld JJ, Park Y, Kleiner DE, Everhart JE, Liang TJ, Hoofnagle JH Increased caffeine consumption is associated with reduced hepatic fibrosis. Hepatology. 2010; 51:201-9.

23. Molloy JW, Calcagno CJ, Williams CD, Jones FJ, Torres DM, Harrison SA Association of coffee and caffeine consumption with fatty liver disease, nonalcoholic steatohepatitis, and degree of hepatic fibrosis. Hepatology. 2012;55:429-36.

24. Myncis M. Hepatite alcoólica. In: Mattos AA \& Dantas-Correa EB. Tratado de Hepatologia. Ed Rubio, 2010. p. 357-369. (Cohen RV, Roll S, Schaffa TD. Hernioplastia incisional videolaparoscópica. Rio de Janeiro: Reichmann \& Affonso, 1999. p. 127-31.)

25. Nakanishi N, Nakamura K, Nakajima K, Suzuki K, Tatara K. Coffee consumption and decreased serum gamma-glutamyltransferase: a study of middle-aged Japanese men. Eur J Epidemiol. 2000;16:419-23.

26. Paluska SA. Caffeine and exercise. Curr Sports Med Rep. 2003;2:213-9.

27. Poynard T, Bedossa P, Opolon P. Natural history of liver fibrosis progression in patients with chronic chronic hepatites C. Lancet. 1997;349:825-32.

28. Purnak T, Ozaslan E. Coffee intake and chronic hepatitis C. Hepatology. 2009;50:1673.

29. Ruhl CE, Everhart JE. Coffee and caffeine consumption reduce the risk of elevated serum alanine aminotransferase activity in the United States. Gastroenterology. 2005; 128:24-32.

30. Sããksjãkvi K, Knekt P, Rissanen H, Laaksonen MA, Reunanen A, Mãnnistõ S Prospective study of coffee consumption and risk of Parkinson's diseases. Eur J Clin Nutr. 2008;62:908-15.

31. Shapiro H, Bruck R. Coffee and tea consumption and chronic liver disease Gastroenterology 2006; 130:1931-2.

32. Shimazu T, Tsubono Y, Kuriyama S, Ohmori K, Koizumi Y, Nishino Y, et al Coffee consumption and the risk of primary liver cancer: pooled analysis of two prospective studies in Japan. Int J Cancer. 2005;116:150-4.

33. Sinha RA, Farah BL, Singh BK, Siddique MM, Li Y, Wu Y, et al. Caffeine stimulates hepatic lipid metabolism via autophagy-lysosomal pathway. Hepatology. 2014;59(4):1366-80.

34. Tfouni SAV, Camargo MCR, Vitorino SHP, Menegário TF, Toledo MCF. Contribuição do guaraná em pó (Paullinia cupana) como fonte de cafeína na dieta. Rev Nutr. 2007;20:63-8.

35. Tverdal A, Skurtveit S. Coffee intake and mortality from liver cirrhosis. Ann Epidemiol. 2003;13:419-23.

36. WHO expert consultation. Appropriate body-mass index for Asian populations and its implications for policy and intervention strategies. The Lancet. 2004;157-63. 